\title{
DOSIS DAN LAMA FERMENTASI KULIT BUAH MARKISA (Passiflora edulis var.edulis) OLEH Phanerochaete chrysosporium TERHADAP KUALITAS FISIK DAN KIMIA PAKAN
}

\section{Dose and Duration Fermentation (Passiflora edulis var. edulis) by Phanerochaete chrysosporium on The Physical and Chemical Feed Quality}

\author{
Wahyu Cristine A. Br Pinem ${ }^{1}$, Ma'ruf Tafsin ${ }^{2}$, dan Tri Hesti Wahyuni ${ }^{2}$ \\ 1. Mahasiswa Program Studi Peternakan Fakultas Pertanian Universitas Sumatera Utara \\ 2. Staf Pengajar Program Studi Peternakan Fakultas Pertanian Universitas Sumatera Utara
}

\begin{abstract}
The study aimed to examine the effect of passion fruit hulls flour fermented with Phanerochaete chrysosporium on the physical and chemical feed quality. Research conducted at the Laboratory of Animal Breeding and Reproduction, in June-July 2015. This research used a Factorial Completely Randomized Design $(C R D)$. The treatment consisted of 2 factors : dose inokulum $\left(10^{4} \mathrm{CFU} / \mathrm{g}, 10^{6} \mathrm{CFU} / \mathrm{g}\right)$ and fermentation duration (0;7;14 dan 21 days). Parameters studied were bulk density, compacted bulk density, specific gravity, crude protein and crude fiber content. The result showed that the factor of fermentation duration had significantly different $(P<0,05)$ on the bulk density and the compacted bulk density. The factors dose and the day duration gives highly significantly different $(P<0,01)$ on crude protein and crude fiber content. While the interaction between dose and fermentation duration is only found in a bulk density and crude protein content. The conclusion of this study that the best dose is $10^{6} \mathrm{CFU} / \mathrm{g}$ with duration 14 days to ferment passion fruit hulls by Phanerochaete chrysosporium .
\end{abstract}

Keywords : Passion Fruit Hulls, Dose, Duration of fermentation, Phanerochaete chrysosporium, Physical quality, Chemical quality.

\begin{abstract}
ABSTRAK
Penelitian ini bertujuan untuk melihat pengaruh fermentasi tepung kulit buah markisa dengan Phanerochaete chrysosporium terhadap kualitas fisik dan kimia pakan. Penelitian dilaksanakan di Laboratorium Pemuliaan dan Reproduksi Ternak, pada bulan juni-juli 2015. Rancangan yang digunakan adalah rancangan acak lengkap (RAL) pola faktorial. Perlakuan terdiri dari 2 faktor yaitu dosis inokulum $\left(10^{4} \mathrm{CFU} / \mathrm{g}, 10^{6} \mathrm{CFU} / \mathrm{g}\right)$ dan lama fermentasi $(0 ; 7 ; 14$ dan 21 hari). Parameter yang diteliti adalah kerapatan tumpukan, kerapatan pemadatan tumpukan, berat jenis, kandungan protein kasar dan kandungan serat kasar. Hasil penelitian menunjukkan bahwa faktor lama hari berpengaruh nyata $(\mathrm{P}<0,05)$ terhadap kerapatan tumpukan, kerapatan pemadatan tupukan dan berat jenis. Faktor dosis dan lama hari masing-masing memberikan pengaruh sangat nyata $(\mathrm{P}<0,01)$ terhadap kandungan protein kasar dan serat kasar. Sedangkan interaksi antara dosis dan lama fermentasi hanya terdapat pada kerapatan tumpukan dan kandungan protein kasar. Kesimpulan dari penelitian ini adalah dosis $10^{6} \mathrm{CFU} / \mathrm{g}$, lama fermentasi terbaik 14 hari dan interaksi terbaik adalah dosis $10^{6} \mathrm{CFU} / \mathrm{g}$ dengan lama fermentasi 14 hari untuk memfermentasi kulit buah markisa oleh Phanerochaete chrysosporium.
\end{abstract}

Kata kunci : Kulit Buah Markisa, Dosis, Lama fermentasi, Phanerochaete chrysosporium, kualitas fisik, kualitas kimia

\section{PENDAHULUAN}


Kulit buat markisa merupakan limbah yang masih belum diimanfaatkan secara maksimal sehingga menjadi limbah yang mencemari lingkungan, sedangkan kulit markisa memiliki potensi dalam memenuhi kebutuhan pakan baik dari segi nutrisi dan kuantitas. Kulit buah markisa merupakan salah satu limbah pengolahan buah markisa menjadi produk minuman (sari markisa) yang mempunyai potensi yang cukup besar. Secara nasional, sentra produksi markisa terletak di Sumatera Utara dan Sulawesi Selatan. Di Sumatera Utara sendiri, industri pengolahan hortikultura menjadi pangan cukup berkembang. Satu pabrik pengolahan buah markisa menjadi produk minuman (sari markisa) mampu berproduksi 10-15 ton per hari dengan limbah berupa biji dan kulit buah sebanyak 2-3 ton per hari. Limbah tersebut belum dimanfaatkan dan malah membutuhkan biaya untuk penanganannya.

Kandungan nutrisi kulit buah markisa adalah protein kasar (\% PK) 12,37\%, lemak kasar (\% LK) 5,28\%, serat kasar (\% SK) 30,16\% dan abu 9,26\% sehingga kulit buah markisa ini dapat dimanfaatkan sebagai bahan baku pakan ternak. Adanya kandungan zat antinutrisi membuat kulit buah markisa membutuhkan sentuhan teknologi sebelum dijadikan sebagai bahan pakan. Pengolahan kulit buah markisa segar menjadi bahan baku pakan dilakukan melalui proses secara biologi dan kimia. Proses secara biologi antara lain pencucian kulit markisa, pencacahan, pengeringan dan pembuatan tepung. Semua tahapan proses biologis tersebut bertujuan untuk penanganan kandungan tannin dalam kulit buah markisa. Proses kimia untuk penanganan serat kasar dan peningkatan protein kasar antara lain dengan melakukan fermentasi menggunakan kapang Phanerocaete chrysosporium yang memiliki kemampuan mendegradasi serat kasar terutama lignin dengan baik.

Berdasarkan uraian diatas, penulis berkeinginan melakukan penelitian terhadap pengaruh dosis inokulum dan lama fermentasi yang berbeda dengan menggunakan Phanerochaete chrysosporium terhadap kualitas fisik dan kimia tepung kulit buah markisa.

\section{BAHAN DAN METODE PENELITIAN}

\section{Lokasi dan Waktu Penelitian}

Penelitian dilaksanakan di Laboratorium Pemuliaan dan Reproduksi Ternak Program Studi Peternakan Fakultas Pertanian Universitas Sumatera Utara. Penelitian ini dimulai bulan juni sampai dengan juli 2015.

\section{Bahan dan Alat Penelitian}


Bahan yang digunakan kulit buah markisa yang dikeringkan di bawah sinar matahari dan digiling menjadi tepung, jamur Phanerochaete chrysosporium sebagai fermentator. Potatoes Dextrose Agar (PDA) sebagai media pembiakan jamur.

Alat yang digunakan hot plate atau kompor, pemanas spiritus, labu elemenyer, kapas steril, aluminium foil, ose, tabung reaksi, cawan petri, kertas saring, plastik bening, timbangan elektronik, oven dan alat tulis.

\section{Metode Penelitian}

Metode penelitian yang digunakan adalah secara experimental dengan menggunakan rancangan acak lengkap (RAL) faktorial, dengan dua faktor yaitu lama waktu fermentasi dan dosis inokulum yang masing-masing faktor terdiri dari:

I. Faktor dosis inokulum dengan 2 taraf :

$\mathrm{K}_{1} \quad=10^{4} \mathrm{CFU} / \mathrm{gram}$ Phanerochaete chrysosporium

$\mathrm{K}_{2}=10^{6} \mathrm{CFU} /$ gram Phanerochaete chrysosporium

II. Faktor lama fermentasi dengan 4 taraf :

$\mathrm{P}_{0} \quad=$ fermentasi 0 hari (Tanpa Fermentasi)

$\mathrm{P}_{1} \quad=$ fermentasi 7 hari

$\mathrm{P}_{2} \quad=$ fermentasi 14 hari

$\mathrm{P}_{3} \quad=$ fermentasi 21 hari

\section{Parameter Penelitian}

\section{A. Uji kualitas fisik pakan}

1. Kerapatan Tumpukan (Khalil, 1999a)

Kerapatan tumpukan $=\frac{\text { Berat Bahan }(\mathrm{kg})}{\text { Volume Ruang }\left(\mathrm{m}^{3}\right)}$

2. Kerapatan Pemadatan Tumpukan (Khalil, 1999a)

Kerapatan pemadatan tumpukan $=$ Berat bahan $(\mathrm{kg})$

Volume setelah pemadatan $\left(\mathrm{m}^{3}\right)$

\section{Berat Jenis (Khalil, 1999a)}

Berat Jenis $=\frac{\text { Berat Bahan }(\mathrm{kg})}{\text { Perubahan Volume Aquades }\left(\mathrm{m}^{3}\right)}$

\section{B. Uji kimia pakan}

1. Kadar serat kasar (AOAC, 1995)

\% Serat Kasar

$(B-(A+C))$ 


\section{$\overline{\text { Berat Sampel }}$}

Keterangan : $\quad \mathrm{A}=$ Berat kertas saring $(\mathrm{g})$

$\mathrm{B}=$ Berat kertas saring + berat sampel $(\mathrm{g})$

$\mathrm{C}=$ Berat Abu $(\mathrm{g})$

\section{Kadar protein (AOAC, 1995)}

$\%$ Protein $=\frac{\text { Volume } \mathrm{HCl} \times \mathrm{N} \mathrm{HCl} \times 14,01 \times 6,25 \times \mathrm{FP}}{\mathrm{mg} \mathrm{sampel}} \times 100 \%$

Keterangan : FP $=$ Faktor Pengenceran

\section{HASIL DAN PEMBAHASAN}

\section{Uji Kualitas Fisik Pakan}

\section{Kerapatan Tumpukan $\left(\mathrm{kg} / \mathrm{m}^{3}\right)$}

Hasil analisis ragam menunjukan bahwa faktor lama fermentasi memberikan pengaruh sangat nyata $(\mathrm{P}<0,01)$ sedangkan faktor dosis memberikan pengaruh tidak berbeda nyata $(\mathrm{P}>0,05)$ terhadap nilai kerapatan tumpukan tepung kulit markisa serta tidak terdapat interaksi antar faktor. Dari hasil uji lanjut (Duncan's Multiple Range Test) yang dilakukan menunjukan bahwa nilai kerapatan tumpukan kulit buah markisa pada lama fermentasi 7 hari lebih tinggi di bandingkan dengan lama fermentasi 0, 14 dan 21 hari.

Meningkatnya nilai kerapatan tumpukan disebabkan karena semakin halus atau semakin kecil ukuran partikel akibat dari hasil kerja kapang Phanerochaete chrysosporium yang mendegradasi serat kasar seiring dengan lama fermentasi, sem akin rendah kandungan serat kasar maka tekstur substrat juga semakin halus. Hal ini sesuai dengan pernyataan Johnson (1994), yang menyatakan bahwa banyak jumlah partikel halus dalam ransum, maka akan meningkatkan nilai kerapatan tumpukan.

Tabel 1. Nilai Kerapatan Tumpukan, Kerapatan Pemadatan Tumpukan dan Berat Jenis tepung kulit buah markisa yang difermentasi dengan Phanerochaete chrysosporium.

\begin{tabular}{lcccccc}
\hline \multirow{2}{*}{ Parameter } & $\begin{array}{c}\text { Dosis } \\
(\mathrm{CFU} / \mathrm{g})\end{array}$ & 0 & 7 & 14 & 21 & \multirow{2}{*}{$\begin{array}{c}\text { Rata-rata } \\
\left(\mathrm{kg} / \mathrm{m}^{3}\right)\end{array}$} \\
\cline { 3 - 6 } Kerapatan & $10^{4}$ & 333,33 & 430,00 & 376,67 & 323,33 & $365,83^{\mathrm{a}}$ \\
Tumpukan & $10^{6}$ & 333,33 & 420,00 & 426,67 & 336,67 & $381,67^{\mathrm{a}}$ \\
\hline \multicolumn{2}{l}{ Rata-rata $\left(\mathrm{kg} / \mathrm{m}^{3}\right)$} & $338,33^{\mathrm{B}}$ & $425,00^{\mathrm{A}}$ & $401,67^{\mathrm{A}}$ & $330,00^{\mathrm{B}}$ & \\
\hline Kerapatan & $10^{4}$ & 444,44 & 459,26 & 433,77 & 421,67 & $439,79^{\mathrm{a}}$ \\
$\begin{array}{l}\text { Pemadatan } \\
\text { Tumpukan }\end{array}$ & $10^{6}$ & 430,03 & 442,11 & 501,96 & 420,83 & $448,73^{\mathrm{a}}$ \\
\hline \multicolumn{2}{l}{ Rata-rata $\left(\mathrm{kg} / \mathrm{m}^{3}\right)$} & $437,24^{\mathrm{BC}}$ & $450,69^{\mathrm{AB}}$ & $467,87^{\mathrm{A}}$ & $421,25^{\mathrm{C}}$ & \\
\hline
\end{tabular}




\begin{tabular}{lcccccc}
\hline \multirow{2}{*}{ Berat Jenis } & $10^{4}$ & 236,25 & 234,93 & 242,07 & 234,41 & $236,92^{\mathrm{a}}$ \\
& $10^{6}$ & 234,41 & 247,97 & 241,97 & 229,03 & $238,35^{\mathrm{a}}$ \\
\hline \multicolumn{2}{l}{ Rata-rata $\left(\mathrm{kg} / \mathrm{m}^{3}\right)$} & $235,33^{\mathrm{AB}}$ & $241,45^{\mathrm{A}}$ & $242,02^{\mathrm{A}}$ & $231,72^{\mathrm{B}}$ & \\
\hline
\end{tabular}

Keterangan : Superskrip yang berbeda pada baris atau kolom yang sama menunjukkan perbedaan yang nyata $(\mathrm{P}<0,05)$ atau sangat nyata $(\mathrm{P}<0,01)$

Penurunan nilai kerapatan tumpukan juga dapat disebabkan karena menurunnya kadar air substrat yang merupakan akibat dari pemecahan karbohidrat substrat oleh mikroba yang menghasilkan zat sisa berupa $\mathrm{CO}_{2}$ dan $\mathrm{H}_{2} \mathrm{O}$ dan juga dapat disebabkan oleh menumpuknya misellium kapang apabila waktu fermentasi terlalu lama. Al-Mahasneh dan Rababah (2007), menyatakan bahwa ukuran partikel meningkat seiring dengan meningkatnya kadar air dan penurunan nilai kerapatan tumpukan kemungkinan disebabkan karena mengerasnya substrat yang disebabkan pertumbuhan kapang yang lebat.

\section{Kerapatan Pemadatan Tumpukan $\left(\mathrm{kg} / \mathrm{m}^{3}\right)$}

Hasil analisis ragam menunjukan bahwa faktor dosis memberikan pengaruh tidak berbeda nyata $(\mathrm{P}<0,05)$, sedangkan faktor lama hari fermentasi memberikan pengaruh yang berbeda nyata $(\mathrm{P}<0,05)$ terhadap kerapatan pemadatan tepung kulit buah markisa. Dari hasil uii lanjut (Duncan's Multiple Range Test) yang dilakukan juga menunjukan bahwa nilai kerapatan pemadatan tumpukan kulit buah markisa untuk dosis $10^{6} \mathrm{CFU} / \mathrm{g}$ ditunjukan pada lama fermentasi hari ke-14 namun pada dosis $10^{4} \mathrm{CFU} / \mathrm{g}$ nilai kerapatan pemadatan tumpukan tertinggi ditunjukkan pada lama fermentasi hari ke-7.

Penurunan nilai kerapatan pemadatan tumpukan dapat dipengaruhi oleh tekstur substrat atupun ukuran partikel. Apabila ukuran partikel semkin besar dan maka tekstur yang dihasilkan semakin kasar sehingga waktu yang di butuhkan pada saat pencurahan semakin lama. Interaksi antara kedua faktor memberikan pengaruh yang nyata $(\mathrm{P}<0,05)$ terhadap peningkatan kerapatan pemadatan tepung kulit buah markisa. Dan interaksi dengan nilai terbaik ditunjukan pada dosis $10^{6} \mathrm{CFU} / \mathrm{g}$ dengan lama fermentasi 14 hari sebesar 501,96 $\mathrm{kg} / \mathrm{m}^{3}$.

Nilai kerapatan pemadatan tumpukan yang semakin besar menunjukan bahwa kemampuan memadat substrat semakin tinggi dan sebaliknya. Hal ini sesuai dengan pernyataan Rikmawati (2005) yang menyatakan bahwa kerapatan pemadatan tumpukan yang tinggi berarti bahan memiliki kemampuan memadat yang tinggi dibandingkan dengan bahan yang lain. Semakin rendah kerapatan pemadatan tumpukan yang dihasilkan maka laju alir semakin menurun. 


\section{Berat Jenis $\left(\mathrm{kg} / \mathrm{m}^{3}\right)$}

Hasil analisis ragam menunjukan bahwa faktor lama fermentasi memberikan pengaruh yang nyata $(\mathrm{P}<0,05)$ sedangkan faktor dosis memberikan pengaruh tidak berbeda nyata $(\mathrm{P}<0,05)$ terhadap nilai berat jenis tepung kulit buah markisa serta tidak ada interaksi dari kedua faktor. Dari hasil uji lanjut (Duncan's Multiple Range Test) yang dilakukan juga menunjukan bahwa nilai berat jenis kulit buah markisa pada lama fermentasi 14 hari lebih tinggi di bandingkan dengan lama fermentasi 0,7 dan 21 hari.

Peningkatan dan penurunan nilai berat jenis kemungkinan disebabkan oleh perubahan kandungan kadar air serta ukuran partikel yang semakin halus dan semakin kasar akibat dari lama fermentasi yang apabila terlalu lama akan menghasilkan pertumbuhan kapang Phanerocate chrysosporium yang lebat yang menghasilkan banyak misellium yang mempengaruhi tingkat kehalusan tekstur substrat. Hal ini didukung oleh pernyataan Gautama (1998), yang menyatakan bahwa berat jenis dipengaruhi oleh komposisi kimia pakan. Gautama (1998), juga menyatakan bahwa menurunnya nilai berat jenis disebabkan ruang antar partikel bahan sudah terisi oleh aquades dalam pengukuran sehingga nilai berat jenisnya rendah. Apabila partikel semakin kasar maka ukuran partikel semakin besar dan kerapatan semakin menurun sehingga air lebih mudah mengisi ruang antara partikel.

Nilai berat jenis yang semakin tinggi menunjukan bahwa kemampuan homogenitas substrat dalam pencampuran bahan pembuatan pellet semakin tinggi serta mengisi ruang udara lebih rapat. Semakin tinggi nilai berat jenis maka kapasitas ruang penyimpanan semakin besar serta proses pengangkutan semakin mudah. Hal ini didukung oleh pernyataan Syarifudin (2001), yang menyatakan semakin tinggi berat jenis maka akan semakin meningkatkan kapasitas ruang penyimpanan dan memudahkan pengangkutan.

\section{Uji Kimia Pakan}

\section{Protein Kasar}

Hasil analisis ragam menunjukan bahwa faktor dosis, faktor lama fermentasi serta interaksi antar kedua faktor masing-masing memberikan pengaruh yang sangat berbeda nyata $(\mathrm{P}<0,01)$ terhadap kandungan protein kasar tepung kulit buah markisa. Dari hasil uji lanjut (Duncan's Multiple Range Test) yang dilakukan menunjukan bahwa kadar protein kasar yang tertinggi terdapat pada dosis $10^{6} \mathrm{CFU} / \mathrm{g}$ dengan lama fermentasi 21 hari. 
Tabel 2. Kandungan protein kasar dan serat kasar tepung kulit buah markisa fermentasi Phanerocaete chrysosporium

\begin{tabular}{|c|c|c|c|c|c|c|}
\hline \multirow[t]{2}{*}{ Parameter } & \multirow{2}{*}{$\begin{array}{c}\text { Dosis } \\
(\mathrm{CFU} / \mathrm{g})\end{array}$} & \multicolumn{4}{|c|}{ Lama Fermentasi (Hari) } & \multirow{2}{*}{$\begin{array}{c}\text { Rata-rata } \\
\left(\mathrm{kg} / \mathrm{m}^{3}\right)\end{array}$} \\
\hline & & 0 & 7 & 14 & 21 & \\
\hline Protein & $10^{4}$ & 8,50 & 11,88 & 15,06 & 16,30 & $12,94^{\mathrm{B}}$ \\
\hline Kasar & $10^{6}$ & 8,50 & 13,02 & 17,91 & 18,03 & $14,37^{\mathrm{A}}$ \\
\hline \multicolumn{2}{|c|}{ Rata-rata $\left(\mathrm{kg} / \mathrm{m}^{3}\right)$} & $8,50^{\mathrm{D}}$ & $12,45^{\mathrm{C}}$ & $16,49^{\mathrm{B}}$ & $17,17^{\mathrm{A}}$ & \\
\hline Serat & $10^{4}$ & 39,57 & 38,27 & 36,51 & 37,57 & $37,98^{\mathrm{A}}$ \\
\hline Kasar & $10^{6}$ & 39,57 & 37,65 & 35,27 & 36,38 & $37,22^{\mathrm{B}}$ \\
\hline \multicolumn{2}{|c|}{ Rata-rata $\left(\mathrm{kg} / \mathrm{m}^{3}\right)$} & $39,57^{\mathrm{A}}$ & $37,96^{\mathrm{B}}$ & $35,89^{\mathrm{D}}$ & $36,98^{\mathrm{C}}$ & \\
\hline
\end{tabular}

Ket : Superskrip yang berbeda pada baris atau kolom yang sama menunjukkan perbedaan yang sangat nyata $(\mathrm{P}<0,01)$

Pengaruh dosis yang terbaik terhadap kandungan protein kasar adalah $10^{6} \mathrm{CFU} / \mathrm{g}$ dengan dengan nilai rata-rata $14,37 \%$ dan pada dosis $10^{4} \mathrm{CFU} / \mathrm{g}$. Sedangkan interaksi terbaik ditunjukan oleh dosis $10^{6} \mathrm{CFU} / \mathrm{g}$ dengan lama fermentasi 21 hari dengan nilai rata-rata sebesar 18,03\%. Dari hasil uji lanjut (Duncan's Multiple Range Test) yang dilakukan menunjukan bahwa kadar protein kasar yang tertinggi terdapat pada dosis $10^{6} \mathrm{CFU} / \mathrm{g}$ dengan lama fermentasi 21 hari.

Salah satu penyebab kandungan protein meningkat disebabkan biokonversi dari komponen anorganik menjadi bahan organik yaitu adanya kerja optimal kapang Phanerocaete chrysosporium yang mengubah komponen anorganik menjadi bahan organik, namun peningkatan kadar protein yang paling dominan selama proses fermentasi berlangsung juga dikarenakan adanya penambahan protein yang disumbangkan dari tubuh kapang fermentator itu sendiri atau juga disebut sebagai protein sel tunggal (single cell protein). Oleh karena itu semakin lama proses fermentasi maka semakin banyak mikroba yang dihasilkan dan akan menyebabkan peningkatan protein yang semakin tinggi pula.

Nelson dan Suparjo (2011) juga menyatakan bahwa peningkatan kandungan protein terjadi karena biokonversi kandungan gula menjadi protein miselium atau protein sel tunggal. Sekresi enzim ektraseluler oleh $P$. chrysosporium turut berperan dalam meningkatkan kandungan protein.

\section{Serat Kasar}


Serat kasar suatu bahan pakan merupakan komponen kimia yang besar pengaruhnya terhadap pencernaan yang merupakan sisa makanan yang tinggal setelah proses pencernaan asam dan basa.

Hasil analisis ragam menunjukan bahwa faktor dosis dan faktor lama fermentasi masing-masing memberikan pengaruh yang sangat berbeda nyata $(\mathrm{P}<0,01)$ terhadap kandungan serat kasar tepung kulit buah markisa. Namun tidak ada pengaruh interaksi dari kedua faktor.

Penurunan kadar serat kasar diakibatkan hasil dari kerja mikroba fermentator yang memanfaatkan substrat sebagai sumber makanannya yang digunakan untuk berkembangbiak dan bertahan hidup. Dan pola penurunan serat kasar pada penelitian ini secara konstant berkisar 7-14 hari. Pada rentang waktu ini menunjukan bahwa semakin lama waktu fermentasi maka kandungan serat kasar akan semakin menurun. Hal ini didukung oleh pernyataan Ginting dan Rantan (2006) dalam penelitiannya terhadap BIS yang menyatakan bahwa lama inkubasi 9 atau 12 hari dapat dianggap sebagai masa inkubasi optimal.

Sedangkan peningkatan kadar serat kasar dipengaruhi oleh lama fermentasi yang terlalu lama, lama waktu fermentasi yang lebih dari 7-14 hari maka akan mengakibatkan semakin banyak pula populasi kapang fermentator Phanerocate chrysosporium yang dihasilkan yang menyumbangkan banyak misellium sehingga menjadi sumber serat pada substrat dan pertumbuhan misselium tersebut tidak seimbang dengan enzim pemecah yang dihasilkan oleh fermentator. Hal ini sesuai dengan pernyataan Uhi (2007) bahwa penurunan kadar serat kasar diakibatkan karena adanya kerja dari mikroba dalam pemanfaatan media sebagai sumber energinya yang digunakan selama proses fermentasi berlangsung dan untuk kebutuhan hidup tubuh mikroba itu sendiri. Hal ini juga didukung oleh pernyataan Ginting dan Rantan (2006) dalam penelitiannya yang menyatakan bahwa lama inkubasi yang semakin panjang menyebabkan terjadinya peningkatan kandungan serat kasar pada substrat. Hal ini diduga disebabkan oleh menurunnya kadar air pada substrat, sehingga serat kasar semakin terkonsentrasi. Disamping itu, perkembangan kapang Phanerocate chrysosporium yang secara konsisten meningkat menurut masa fermentasi dapat menyumbang serat kasar melalui dinding selnya.

\section{KESIMPULAN}

Faktor dosis inokulum kapang Phanerocate chrysosporium tidak meningkatkankan nilai kerapatan tumpukan, kerapatan pemadatan tumpukan dan berat jenis, tetapi dapat 
meningkatkan kadar protein kasar dan menurunkan kadar serat kasar tepung kulit buah markisa, dan tidak ada interaksi antar faktor.

\section{DAFTAR PUSTAKA}

AL-Mahasneh, M. A. and T.M. Rababah. 2007. Effect Moisture of Content on Some Physical Properties of Green Wheat. J. Food Engineering, 79 (4): 1467-1473.

AOAC, 1995. Official Methods of Analysis of the Assocation of Analytical Chemist, Washington D.C.

Gautama, P. 1998. Sifat Fisik Pakan Lokal Sumber Energi, Sumber Mineral serta Hijauan pada Kadar Air dan Ukuran Partikel yang Berbeda [Skripsi]. Fakultas Peternakan. Institut Pertanian Bogor.

Ginting, S.P. dan Rantan K. 2006. Pengaruh Fermentasi Menggunakan Beberapa Strain Trichoderma dan Masa Inkubasi Berbeda Terhadap Komposisi Kimiawi Bungkil Inti Sawit. Seminar Nasional Teknologi Peternakan dan Veteriner.

Johnson, J.R. 1994. The realities of bulk solid propeerties testing. Bulk Solid handling, 14(!): 129-134.

Khalil.1999a. Pengaruh Kandungan Air dan Ukuran Partikel Terhadap Sifat Fisik Pakan Lokal; Kerapatan Tumpukan, Kerapatan Pemadatan Tumpukan dan Berat Jenis. Media Peternakan. 22(1):1-11

Nelson dan Suparjo. 2011. Penentuan Lama Fermentasi Kulit Buah Kakao dengan Phanerochaete chrysosporium : Evaluasi Kualitas Nutrisis secara Kimia. AGRINAK Vol. 01. No. 1. September $2011 ; 1-10$.

Rikmawati, W. 2005. Pengaruh Substitusi Tepung Ikan Impor dengan Corn Gluten Meal Terhadap Laju Alir Pakan Pellet Broiler Finisher Pada Sistem Produksi Continous [Skripsi]. Fakultas Peternakan. Institut Pertanian Bogor, Bogor.

Syarifuddin, U.H. 2001. Pengaruh Penggunaan Tepung Gaplek sebagai Perekat Terhadap Sifat Fisik Ransum Broiler Bentuk Crumble [Skripsi]. Fakultas Peternakan. Institut Pertanian Bogor, Bogor.

Uhi, H.T. 2007. Peningkatan Nilai Nutrisi Ampas Sagu (Metroxylon sp) melalui BioFermentasi. Jurnal Ilmu Ternak, vol.7 no. 1, 26-31. 